ABDI: Jurnal Pengabdian dan Pemberdayaan Masyarakat ISSN: 2656-369X (Print), 2684-8570 (Online)

Volume 2 No. 2, Desember 2020

http://abdi.ppj.unp.ac.id/index.php/abdi

Email: abdi@ppj.unp.ac.id

DOI: https://doi.org/10.24036/abdi.v2i2.60

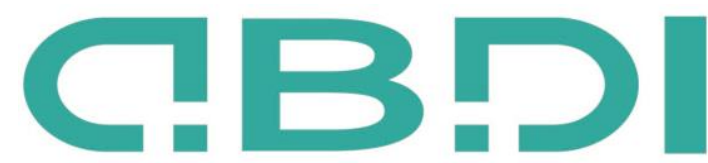

ABDI: JURNAL PENGABDIAN DAN PEMBERDAYAAN MASYARAKAT

\title{
Pelatihan dan Pendampingan Pengembangan Materi Pembelajaran PPKn Kajian Bhinneka Tunggal Ika Berbantuan Website
}

\author{
Winarno Winarno ${ }^{1}$, Rusnaini Rusnaini ${ }^{2}$, Machmud Al Rasyid ${ }^{3}$, Erna Yuliandari ${ }^{4}$ \\ Muchtarom Muchtarom ${ }^{5}$, Anis Suryaningsih ${ }^{6}$ \\ 1,2,3,4,5,6Universitas Sebelas Maret Surakarta \\ E-mail: winarnonarmoatmojo@staff.uns.ac.id,nainirus@staff.uns.ac.id,machmudalrasyid@yahoo.co.id, \\ nana_adenensi@yahoo.co.id, Muhtarom1974@staff.uns.ac.id, anissuryaningsih@staff.uns.ac.id
}

\begin{abstract}
Abstrak
Materi pokok PPKn menurut Kurikulum 2013 ada 4 (empat) yakni Pancasila, UUD 1945, Negara Kesatuan Republik Indonesia dan BhinnekaTunggal Ika. Materi Bhinneka Tunggal Ika merupakan materi baru jika dibanding dengan 3 (tiga) materi sebelumnya. Materi Bhinneka Tunggal Ika sebagai wujud filosofi kesatuan yang melandasi dan mewarnai keberagaman kehidupan bermasyarakat, berbangsa, dan bernegara. Materi Bhinneka Tunggal Ika membelajarkan siswa perihal sikap menghargai dan menghormati keragaman dan perbedaan dalam diri bangsa Indonesia. Materi BhinnekaTunggal Ika penting diberikan dalam rangka menumbuhkan sikap tolerensi, mencegah terjadinya intoleransi, diskriminasi dan gejala radikalisme siswa. Tujuan pengabdian adalah melatih dan mendampingi guru PPKn mengembangkan materi aspek Bhinneka Tunggal Ika berbasis isu aktual yang sejalan dengan Kompetensi Dasar berdasar Kurikulum PPKn 2013 jenjang SMP. Sejalan dengan tujuan tersebut, metode yang digunakan adalah workshop/pelatihan disertai pendampingan dengan menganalisis situasi dan kebutuhan, menetapkan tujuan, mendesain model pelatihan dan pendampingan. Sasaran kegiatan adalah guru-guru PPKn jenjang SMP di Kabupaten Sukoharjo. Hasil kegiatan adalah telah dilakukan pelatihan yang meliputi analisis KI, KD dan Indikator, pendalaman materi keberagaman, dan penyusunan materi kedalam bahan ajar dalam bentuk modul bagi siswa. Modul berisi pembelajaran materi BhinnekaTunggal Ika yang nantinya bisa digunakan guru dan siswa dalam wujud e-modul.
\end{abstract}

Kata Kunci: PPKn, Materi Pembelajaran, Bhinneka Tunggal Ika

\section{Abstract}

According to the 2013 Curriculum, there are 4 (four) main subjects of PPKn, namely Pancasila, UUD 1945, the Unitary State of the Republic of Indonesia and BhinnekaTunggal Ika. Bhinneka Tunggal Ika material is new material when compared to the previous 3 (three) materials. The material of Bhinneka Tunggal Ika is a form of the unity philosophy that underlies and colors the diversity of life in society, nation and state. Unity in Diversity material teaches students about the attitude of respecting and respecting diversity and differences within the Indonesian nation. It is important to give BhinnekaTunggal Ika material in order to foster a tolerant attitude, prevent incidents of intolerance, demonstrations and symptoms of student radicalism. The aim of the service is to train and assist PPKn teachers in developing material aspects of Bhinneka Tunggal Ika based on actual issues that are in line with Basic Competencies based on the 2013 PPKn Curriculum for SMP level. In line with these objectives, the methods used are workshop / mentoring training with needs, designing training and mentoring models. The target of the activity is junior high school PPKn teachers in Sukoharjo Regency. The results of the activity have been carried out by training which includes analysis of KI, KD and Indicators, deepening the diversity of material, and compiling the material into teaching materials in the form of modules for students. The module contains learning materials of BhinnekaTunggal Ika which can later be used by teachers and students in the form of e-modules.

Key Word: PPKn, Learning Materials, Bhineka Tunggal Ika

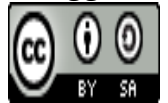

Received: 28 September $2020 \quad$ Revised: 12 November $2020 \quad$ Available Online: 13 November 2020 
Winarno Winanrno, dkk. Pelatihan dan Pendampingan Pengembangan Materi Pembelajaran PPKn Kajian Bhinneka Tunggal Ika Berbantuan Website

\section{Pendahuluan}

Bahan atau materi pelajaran (learning materials) merupakan komponen penting dalam kegiatan pembelajaran. Materi bepengaruh dalam pembentukan pengetahuan, keterampilan dan sikap dalam mencapai kompetensi dasar yang direncanakan. Hal ini sesuai Pedoman Penulisan Buku Pelajaran (Depdiknas; 2005) konten pendidikan mencakup segala sesuatu yang disampaikan pendidik untuk dipahami peserta didik sebagai upaya mencapai kompetensi tertentu. Bahan ajar sebaiknya di susun oleh pendidik yang disesuaikan dengan karakteristik dan kondisi peserta didik. Namun, berdasarkan hasil observasi awal ditemukan guru menggunakan bahan ajar rekomendasi MGMP yang sudah tersedia di pasaran. Bahan ajar yang digunkan oleh guru-guru PPKn di MGMP Kabupaten Sukoharjo terdiri dari buku pendamping pokok dari sekolah, Suplemen Bahan Ajar (SBA) dan Buku pendamping bagi beberapa sekolah yang berada di perkotaan.

Permasalahan selanjutnya yang ditemui di lapangan yaitu guru menggunakan bahan ajar pokok yang berasal dari MGMP berlaku di sebagian besar anggota MGMP. Guru belum mengkritisi kesesuaian materi dan kurikulum. Guru cukup memakai buku acuan dan Suplemen Bahan Ajar (SBA) yang dikembangkan oleh MGMP. SBA lebih menjadi acuan pokok guru-guru PPKn SMP di Kabupaten Sukoharjo. Menurut Depdiknas isi substansi bahan ajar sebagai bentuk akumulasi dari standar kompetensi atau kompetensi dasar dalam kurikuluam. Bahan ajar disesuaikan kebutuhan dan kondisi peserta didik sehingga mudah dipahami dan memiliki daya tarik (Depdiknas;2014). Untuk memenuhi daya tarik peserta didik bahan ajar disusun disesuaikan dengan karakteristik peserta didik. Bahan ajatrtrrsebut harus memenuhi aspek relevansi, kompleksitas, ilmiah, fungsional, kekinian, dan komprehensif/keseimbangan (Tim Pengembang MKDP Kurikulum dan Pembelajaran UPI;2011). Sementara itu bahan ajar dikategorikan baik menurut Puast Kurikulum Buku terdapat empat kategori: kesesuaian dengan kurikulum, penyajian materi sesuai prinsip belajar, bahasa yang baik dan format menarik (Puskurbuk; 2012).

Buku teks menjadi sarana yang berdaya guna bagi pembentukan kesadaran dan identitas bangsa (Anne Gaul, 2015). Buku teks tdak hanya berisi pengetahuan tetapi juga menawarkan ide, gagasan dan nilai untuk generasi yang akan datang, meneggelorakan semangat patriotisme dan kohesifitas bangsa (Benito, 2009, Al-Haj, 2005). Buku teks dipandang sebagai pembawa pesan ideologis guna mewariskan nilai dan kepercayaan bangsa kepada generasi selanjutnya (Opoku-Amankwa, BrewHammond, Kofigah, 2011). Melalui buku teks diharapkan materi pembelajran dapat tersampaikan dengan baik terkait pengetahuan, sikap dan tingkan.

Pelajaran PPKn kurikulum 2013 membawa fungsi sebagai pendidikan karakter dan kebangsaan (Memperkokoh Posisi PKn Sebagai Disiplin Ilmu Terintegrasi_Sapriya, n.d.) yang dapat membawa siswa ke arah pemahaman dan kesadaran akan keberagaman bangsa. Dalam pelajaran PPKn 2013 termuat materi tentang Bhinneka Tunggal Ika bentuk pengejawantahan filosofi kesatuan sebagai dasar keberagaman kehidupan bermasyarakat, berbangsa, dan bernegara. (Kemdikbud, 2016). Materi Bhinneka Tunggal Ika menjadi bagian dari buku teks PPKn untuk siswa.

Sekarang ini kasus atau peristiswa intolerensi, sikap diskriminasi, dan sikap kurang menghargai perbedaan sering ditampilkan di berbagai media. Misalnya kasus yang terjadi si salah satu SMA di kab Sragen dimana gubernur Jawa Tengah Ganjar Parnowo tidak ingin kasus tersebut terulang kembali (https://www.solopos.com/kasus-intoleransi-siswa-di-sragen-ganjar-jangan-terulang-lagi1043287. Ada pula kasus siswa menolak ketua OSIS yang berbeda agama (https://m.tribunnews.com/nasional/2017/05/03/benih-benih-intoleransi-di-sekolah-siswa-tolak-ketuaosis-yang-beda-agama). Selama tahun 2019 ini ditemukan ada 31 (tigapuluh satu) kasus intolerensi di Indonesia (https://www.cnnindonesia.com/nasional/20191117163821-32-449096/imparsial-temukan31-kasus-intoleransi-selama-setahun).

Sikap intoleransi, kurang menghargai perbedaan, sikap diskriminasi bahkan perilaku radikal terhadap kelompok masyarakat lain dimungkinkan dapat membahayakan integrasi dan kelangsungan hidup bangsa Indonesia . Radikalisme tidak hanya ada di lingkungan masyarakat tetapi dapat pula 
Winarno Winanrno, dkk Pelatihan dan Pendampingan Pengembangan Materi Pembelajaran PPKn Kajian Bhinneka Tunggal Ika Berbantuan Website

terjadi di lingkungan pendidikan (Muchith, 2016). Radikalisme bisa membayakan negara Indonesia (Khamid, 2016).

Sikap dan perilaku intoleren, sikap diskriminatif bahkan radikal ditengarai bermula dari kurangnya penghargaan dan penerimaan terhadap keberagaman yang ada. Pemahaman dan kesadaran terhadap adanya keragaman bangsa menjadi penting untuk dimiliki oleh warga negara Indonesia . Salah satu yang bisa dilakukan di dunia pendidikan adalah memberlajarkan siswa tentang pentingnya keragaman dan perbedaan dalam diri bangsa Indonesia.

Permasalahan umum sekarang ini materi buku teks yang bermuatan Bhinneka Tunggal Ika masih amat kurang dan menyajikan uraian terbatas tentang keberagaman dan kesadaran akan perbedaan yang ada.(Utami \& Widiadi, 2016). Buku panduan tentang Empat Pilar Kehidupan berbangsa dan bernegara (MPR RI 2012) menyajikan materi Bhinneka Tunggal Ika dalam uraian yang relatif sedikit. Materi Bhinneka Tunggal Ika sebagai materi yang relatif baru bila dibanding materi utama PPKn lain yang sudah ada yakni Pancasila, UUD 1945 dan Negara Kesatuan Republik Indonesia. Padahal implementasi nilai nilai Bhinneka Tunggal Ika dapat menghadirkan semangat membangun toleransi dan anti diskriminasi pada siswa (Setyaningsih, 2017).

Materi Bhineka Tunggal Ika dinilai penting mengingat kondisi bangsa Indonesia yang multicultural. Indonesia memiliki keragaman agama, ras, suku, budaya, dan golongan. Keberagaman ini perlu dijaga sebagai sebuah keistimewaan. Hal ini sejalan dengan pendapat Wahid, dkk (2019) yang menyatakan keragaman yang ada di Indonesia sebagai plurallitas yang tidak perlu dipertentangkan. Keberagaman tersebut sebagai keistimewaan sebagai kekayaan atas anugerah Tuhan yang harus dihargai dengan tidak membeda-bedakan. Oleh karena itu, konsep keseragaman tidak dapat di paksakan dalam keberagaman dalam bangsa Indonesia.

Konsep Bhineka Tunggal Ika dapat dilihat pada momentum sejarah sumpah pemuda. Pada momentum tersebut pemuda Indonesia sepakat mengikrarkan bertanah air satu, berbahasa satu, bertumpah darah satu, Indonesia. Pada momentum tersebut membuktikan keberagaman yang ada di Indonesia sebagai suatu kenyataan yang ada. Tidak dapat dimusnahkan namun dapat dipelihara dan di optimalisasikan sebagai potensi yang dimiliki oleh bangsa Indonesia. Namun, dewasa ini semangat sumpah pemuda pada pemuda Indonesia perlu dipertanyakan kembali. Hal ini bias dilihat dengan munculnya konflik intoleran yang terjadi di Indonesia. Data yang dihimpun oleh Yayasan Denny JA (Kompas, 2015) latar belakang agama sebagai penyebab terbesar kekerasan yang terjadi di Indonesia. Sedangkan berdasarkan hasil observasi awal pada siswa SMP di Sukoharjo ditemukan bahwa terdapat siswa yang berkonflik atas dasar perbedaan. Perbedaan yang dipermasalahkan antara lain perbedaan klub sepak bola favorit, perbedaan aliran pencak silat. Beberapa gambaran konflik atas dasar perbedaan tersebut membuat tatanan kehidupan yang intoleran dan tidak harmonis.

Pendidikan sebagai salah satu jalur mendidik dan menanamkan nilai kepada generasi penerus bangsa. Pendidikan tidak hanya sebatas memberi pengertian kepada peserta didik namun pendidikan sebagai usaha sadar dalam memberi pemahaman dan menanamkan IQ, EQ dan SQ. hal ini sejalan dengan amanat Undang-Undang No 20 tahun 2003 tentang Sistem Pendidikan Nasional yang mengatur tentang penyelenggaraan pendidikan yang dilaksanakan secara demokratis, berkeadilan serta tidak diskriminatif. Oleh karena itu sudah seharusnya pendidikan di Indonesia menghargai keberagaman. Muatan ini dapat diinternalisasikan melalui materi Bhineka Tunggal Ika pada mata pelajaran PPKn.

Mata pelajaran PPKn merupakan salah satu mata pelajaran wajib yang diberikan sejak jenjang dasar, menengah dan atas. Bahkan dilanjutkan pada jenjang pendidikan tinggi. Permasalahan yang sering ditemui dilapangan yaitu guru mata pelajaran PPKn lebih mengutamakan kognitif dari pada kecerdasar afektif dan psikomotorik lainnya sebagai upaya untuk membentuk karakter warga negara yang baik. Oleh karena itu perlu adanya media, metode dan strategi pembelajaran yang tepat untuk menginternalisasikan nilai Bhineka Tunggal Ika di persekolahan. Penyusunan strategi, model dan media pembelajaran ini perlu disesuaikna dengan kondisi peserta didik dan lingkungannya.

Dampak globalisasi juga berpengaruhg dalam penyusunan buku teks yang diberikan kepada

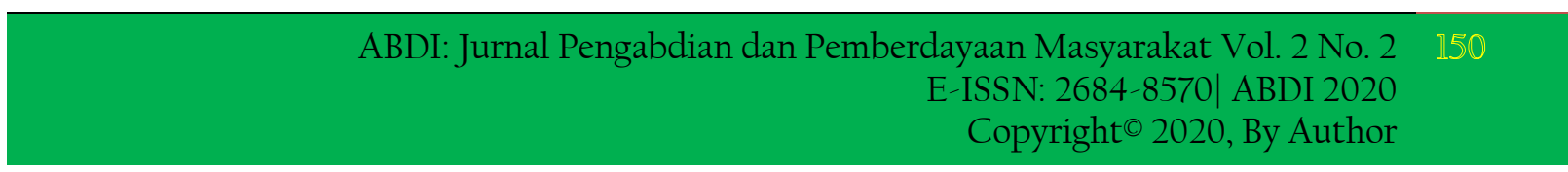


Winarno Winanrno, dkk Pelatihan dan Pendampingan Pengembangan Materi Pembelajaran PPKn Kajian Bhinneka Tunggal Ika Berbantuan Website

peserta didik PPKn tingkat SMP. Peserta didik tingkat SMP rata-rata merupakan generasi yang lahir pada kisaran tahun 2006-2008. Peserta didik pada usia ini tergolong dalam generasi Z. Generasi Z memiliki karakteristik yang akrap dengan teknologi digital. Dampak globalisasi ini dapat digunakan sebagai masukan dalam penyusunan materi bahan ajar. Materi bahan ajar tidak hanya diisusun dalam buku cetak tetapi juga dapat disusun dalam benuk buku elektronik atau ebook. Hal ini akan dapatt mempermudah peserta didik dalam mengakses buku tersebut. Hal ini juga sejalan dnegan kondiisi glonal yang seang berlangsung sekarang ini. Bahwa pembelajaran dilakukan secara daring sehingga bahan ajar akan lebih mudah diakses jika dalam bentuk elektronik.

Berdasarkan uraian diatas, perlu disiusun materi buku teks terkait dengan muatan Bhineka Tunggal Ika pada mata pelajaran PPKn di tingkat SMP. Untuk memberi kemudahan dalam mengakses materi buku teks dapat disusun berupa emateri yang di apload di website unit kerja atau kelas pembelajran di LMS yang guru gunakan. Hal ini sejalan dengan karakteristik generasi alfa yang cenderug familiar dengan gawai dan internet.

\section{Metode Pelaksanaan}

Mitra pengabdian masyarakat adalah guru-guru mata pelajaran PPKn ditingkat SMP di Kabupaten Sukoharjo. Guru mata pelajaran PPKn tersebut tergabung dalam Musyawarah Guru Mata Pelajaran PPKn SMP di Kabupaten Sukoharjo. Musyawarah Guru Mata Pelajaran PKn Sekolah Menengah PertamaKabupaten Sukoharjo disingkat MGMP PKn SMP Sukoharjo. MGMP PKn SMP Sukoharjo memiliki anggota 136 guru PKn di Kabupaten Sukoharjo yang berasal dari 15 Sekolah SMP Swasta dan 32 SMP Negeri. Sekretariat MGMP PKn Sukoharjo di SMP Negeri 6 Sukoharjo dengan alamat Jl. Perkutut Bedingin, Banmati, Kec. Sukoharjo, Kab. Sukoharjo, Prov. Jawa Tengah.

Kegiatan pengabdian masyarakat dengan tema "pengembangan materi pembelajaran ppkn kajian bhinneka tunggal ika berbantuan website" dengan mitra guru-guru PPKn yang tergabung dalam MGMP PPKn Kabupaten Sukoharjo dilaksanakan dalam bentuk pelatihan dan pendampingan yang dilaksanakan pada Senin, 24 Agustus 2020 dilaksanakan secara luar jaringan (luring) di SMPN 3 Sukoharjo. Dihadiri oleh 15 guru PPKn sebagai mitra kegiatan, yg terdiri atas guru klas 7, 8 dan 9 . Pendampingan dilakukan pada Senin, 31 Agustus secara dalam jaringan (daring) melalui zoom meeting. Program pelatihan ini bertujuan untuk melatih dan mendampingi guru PPKn mengembangkan materi aspek Bhinneka Tunggal Ika berbasis isu aktual yang sejalan dengan Kompetensi Dasar berdasar kurikulum PPKn 2013 jenjang SMP.

Tahap perencanaan dilakukan dengan tim pengabdi melakukan survey mitra dan lokasi. Pasa tahap ini pengabdi mengidentifikasi kebutuhan yang diperlukan dan mempersiapkan administrasi pelaksanaan, waktu, tempat dan penganggaran, termasuk mengurus ijin kegiatan. Hal ini digunakan untuk menentukan isi dan materi pelatihan. Pada tahap ini dilakukan penelusuran kebutuhan yang diperlukan guru terkait dengan masalah yang dihadapi guru dalam pembelajaran materi Bhineka Tunggal Ika. Selain itu juga dilakukan penelusuran terhadap sumber bacaan yang digunaan guru dalam matei Bhineka Tunggal Ika. Analisis Kompetensi Dasar dalam kurikulum PPKn SMP tahun 2013 aspek/ruang lingkup Bhinneka Tunggal Ika. Berdasarkan hasil analisa tersebut kemudian dikembangkan pokok pokok materi Bhinneka Tunggal Ika sejalan dengan kompetensi dasar.

Tahap pelaksanaan pengabdian secara garis besar terdiri atas kegiatan pelatihan dan pendampingan. Kegiatan pelatihan dilakukan pada saat tatap muka (in service training) yang dilaksanakan pada Senin, 24 Agustus 2020. Pada tahap ini disampaikan materi terkait dengan pembelajaran materi Bhineka Tunggal Ika. Sedang pendampingan dilakukan pada saat penugasan (on service training) yang dilakukan secara dalam jaringan melalui ruang zoom meeting pada Senin, 31 Agustus 2020. Pada tahap ini dilakukan pendampingan dalam penyusunan materi yang disesuaikan dengan kondisi siswa dan sekolah. Materi yang telah disusun dilakukkan editing dan penataan lay out. Kemudian materi di unggah dalam suatu web site.

Pada tahap evaluasi, dilakukan dengan mengecek ketercapaian indikator kinerja yang telah 
Winarno Winanrno, dkk. Pelatihan dan Pendampingan Pengembangan Materi Pembelajaran PPKn Kajian Bhinneka Tunggal Ika Berbantuan Website

dirancang sebelumnya. Disamping itu juga mengukur tingkat penerimaan peserta terhadap kegiatan ini dengan menyebarkan angket. Dihasilkannya naskah materi ajar PPKn SMP ruang lingkup Bhinneka Tunggal Ika yang diperuntukan untuk siswa.

\section{Hasil dan Pembahasan}

\subsection{Mitra Pengabdian}

MGMP PKn di Kabupaten Sukoharjo sebagai wadah musyawarah guru Mata Pelajaran PKn di Kabupaten Sukoharjo. Melalui organisasi ini guru mata pelajaran PKn berupaya menanamkan nilai karakter bangsa dalam pembelajaran sesuai dengan Pancasila sebagai upaya menuju guru yang profesional, unggul, disiplin dan memenuhi tugas kerja yang meliputi perangkat pembelajaran, bahan ajar, menyusun perangkat penilaian dan penguasaan IT.

Dasar Hukum pelaksanaan MGMP PKn Kabupaten Sukoharjo meliputi:

1. Undang-Undang Dasar Negara Republik Indonesia Tahun 1945, pada Pembukaan alenia 4, Bab XIII Pendidikan, Pasal 31 ayat (1) dan ayat (2),

2. Undang-Undang No. 14 Tahun 2014 Tahun 2005 tentang guru dan dosen,

3. Peraturan Pemerintah Republik Indonesia No. 74 Tahun 2010 tentang Guru,

4. Peraturan Pemerintah Republik Indonesia no. 65 Tahun 2005 Tentang Pedoman Penyusunan dan penerapan Standar Pelayanan Minimal,

5. Peraturan Menteri Pendidikan nasional No. 18 Tahun 2007 tentang Sertifikasi Guru,

Susunan Pengurus MGMP PKn SMP Sukoharjoperiode 2018-2021 sebagai berikut:

1. Koordinator : Drs. Sri Waluyo

2. Ketua I $\quad$ : Drs. Maryono

3. Ketua II : Sutiman, S.Pd.

4. Sekretaris I $U$ : Jardi, S.Pd.

5. Sekretaris II $\longrightarrow \quad$ : Novina Andriani, S.Pd.

6. Bendahara I : Tri Sakti Handayai, S.Pd.

7. Bendahara ii : Erlina subyanti, S. Pd.

8. Seksi kurikulum :Drs. Tari Sisiwanto

9. Seksi Kurikulum : Dra. Sri Rejeki

10. Seksi Kurikulum : Endang Sri Wahyuni, S.Pd.

11. Seksi Pengembangan Profesi : Kardimin, S.Pd., M.Pd.

12. Seksi Humas $\quad$ : Kurlina Fevi Chandra, S.Pd.

13.Seksi Humas : Yani Hastuti, S.Pd.

MGMP PKn Kabupaten Sukoharjo bertujuan meningkatkan kinerja profesi guru mata pelajaran Pendidikan Kewarganegaraan jenjang Sekolah Menengah Pertama di Kabupaten Sukoharjo. Secara khusus MGMP PKn Kabupaten Sukoharjo meningkatkan kompetensi profesional guru dalam pembelajaran melalui diskusi RPP dan RPS Mata Pelajaran PKn. Guru PKn di Kabupaten Sukoharjo memiliki kesulitan dalam penyusunan RPP dan RPS pembelajaran secara individu. Oleh karena itu, guru memanfaatkan MGMP sebagai wadah musyawarah untuk menyusun RPP dan silabus yang dilaksanakan setiap 1 tahun 2 kali.

Nama PKn digunakan sebab MGMP saat itu karena masih mengadopsi pelajaran PKn berdasar kurikulum 2006. Saar ini sejalan dengan perubahan PKn 2006 menjadi PPKn 2013 maka MGMP PKn menjalankan fungsinya terkait dengan pelajaran PPKn 2013. 
Winarno Winanrno, dkk. Pelatihan dan Pendampingan Pengembangan Materi Pembelajaran PPKn Kajian Bhinneka Tunggal Ika Berbantuan Website

Mata Pelajaran PPKn pada jenjang SMP berdasar kurikulum 2013 terdiri dari ruang lingkup (Kemdikbud, 2016):

1. Pancasila, sebagai Dasar Negara, ideologi nasional, dan pandangan hidup bangsa.

2. Undang-Undang Dasar Negara Republik Indonesia Tahun 1945, sebagai hukumdasar tertulis yang menjadi landasan konstitusional kehidupan bermasyarakat, berbangsa, dan bernegara.

3. Negara Kesatuan Republik Indonesia, sebagai kesepakatan final bentuk Negara Republik Indonesia.

4. Bhinneka Tunggal Ika, sebagai wujud filosofi kesatuan yang melandasi dan mewarnai keberagaman kehidupan bermasyarakat, berbangsa, dan bernegara.

\subsection{Analisis Permasalahan Mitra}

Terkait dengan materi ajar PPKn SMP ruang lingkup Bhinneka Tunggal Ika, berdasar wawancara awal dan analisi dokumen awal ditemukan permasalahan yang dihadapi mitra . Yakni 1) materi Bhinneka Tunggal Ika yang terdapat di buku siswa dipandang sedikit dan terlalu normatif, kurang memberikan contoh contoh nyata atau kasus terkait, 2) Materi dalam buku siswa kurang mampu mencerminkan rumusan kompetensi dasar, 3) Guru masih kurang terlatih untuk mencari kasus kasus keragaman dan perbedaan di daerah sendiri ,4) Keterbatasan sarana untuk pencarian sumber secara online, misal karena sinyal lemah, dan 5) Keterbatasan sumber bacaan atau referensi terkait dengan konsep keberagaman dan identitas.

Berdasar permasalahan yang dihadapi mitra di atas, maka akan dilakukan pelatihan dan pendampingan pengembangan materi PPKn SMP ruang lingkup Bhinneka Tunggal Ika. Diharapkan mampu mengembangkan materi Bhinneka Tunggal Ika yang berkait dengan kasus di daerah dan menggunakan bantuan website. Hal ini akan menjadikan materi Bhinneka Tunggal Ika menarik dan memudahkan guru dalam memberikan pemahaman dan kesadaran akan keberagaman dan perbedaan bangsa Indonesia

Agar guru guru PPKn dapat mengembangkan materi Bhinneka Tunggal Ika secara benar dan ilmiah akademik, maka langkah langkah pengembangan materi dilakukan sebagai berikut: 1) menganalisis Kompetensi Dasar dalam kurikulum PPKn SMP tahun 2013, 2) menilai dan mengidentifikasi kelemahan kelemahan materi Bhinneka Tunggal Ika yang tersaji di buku siswa, 3) mengembangkan pokok pokok materi Bhinneka Tunggal Ika sejalan dengan hasil analisis kompetensi dasar, 4) menyusun materi secara kelompok sesuai dengan prinsip prinsip pengembangan bahan ajar , 5) melakukan editing dan lay out materi, 6) mengorganisasikan materi tersebut kedalam file materi berbantuan website. Kegiatan tersebut dilakukan secara workshop tatap muka (in service training) dan penugasan (on service training) dalam jangka waktu tertentu yang telah ditetapkan

\subsection{Pelaksanaan Pengabdian}

Kegiatan pengabdian kepada masyarakat ini dikemas dalam bentuk pelatihan dan pendampingan dengan peserta guru-guru mata pelajaran PPKn yang tergabung dalam MGMP PPKn Kabupaten Sukoharjo. Kegiatan dilaksanakan dalam empat sesi penyampaian materi yang dilakukan oleh tim anggota riset group Filsafat dan Politik Kewarganegaraan

Pada sesi pertama, tim memaparkan materi 1. Materi 1 berisi tentang Analisis KI dan KD subtansi kajian Bhinneka Tunggal Ika jenjang SMP. Materi ini disampaikan oleh Drs. Machmud AR SH MSi. Materi ini berisi tentang KI dan KD yang memuat tentang kajian Bhineka Tunggal Ika yang terdapat pada mata pelajaran PPKn dijenjang SMP yang tersebar pada jenjang kelas VII, VIII dan IX. Dengan materi iini peserta diajak untuk lebih mengenali KI dan KD yang memuat tentang kajian Bhineka Tunggal Ika. Dari materi yang diberikan peserta memahami KI dan KD yang termuat pada mata pelajaran PPKn. Hal ini dirinjau dari jawaban peserta dalam menganalisas dan mengemlompokan bahan kajian Bhineka Tunggal Ika. 
Winarno Winanrno, dkk. Pelatihan dan Pendampingan Pengembangan Materi Pembelajaran PPKn Kajian Bhinneka Tunggal Ika Berbantuan Website

Pada sesi kedua kegiatan diisi dengan materi pengayaan: Keberagaman dan isu kewarganegaraan. Materi kedua ini disampaikan dengan model pemaparan tentang keragaman yang ada di Indonesia disertai dengan pemberian contoh isu-isu kewarganegaraan di Indonesia. Selain itu peserta juga diarahkan dalam mengaitkan dengan materi Bhineka Tinggal Ika. Adapun metode yang digunakan ceramah, presentasi dan diskusi. Diskusi yang dilakukan berkait dengan isu kewarganegaraan dan pemanfaatan materi keberagaamaan dan isu kewarganegaraan dalam memaparkan materi Bhineka Tunggal Ika.

Selanjutnya pada sesi ketiga disampaikan Materi pengayaan kedua yaitu Pentingnya persatuan dalam keberagaman di Indonesia. Pada materi ini dipaparkan tentang urgensi perrsatuan dalam menyikapi keberagamman yang ada di Indonesia dikaitkan dengan materi Bhineka Tunggal Ika. Kemudian dilanjutkan penyampaan materi 4 yaitu mengorganisasikan materi Bhinneka Tunggal Ika dalam e-materi. Setelah materi pengayaaan 1 dan 2 kemudian peserta dibimbing dalam mengorganisasikan materi Bhineka Tunggal Ika dengan menginternalisasikan materi keragaman, isu kontemporer dan semangat persatuan yang disesuaikan dengan isu terkini ke dalam emateri atau materi digital,. Pada tahap ini selanjutnya dilakukan penugasan kepada peserta untuk menyusun materi Bhineka Tunggal Ika sesuai dengan jenjang kelas masing-masing guru.

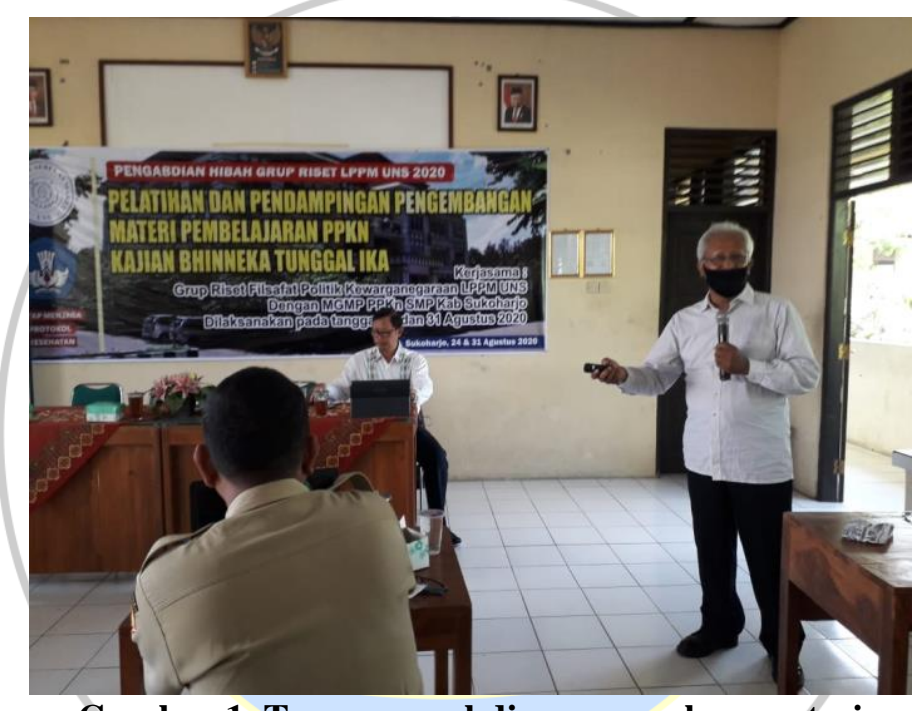

Gambar 1. Team pengabdi memaparkan materi

Pada Senin, 31 Agustus 2020 dilakukan pendampingan dalam penyusunan emateri. Pada tahap ini dilakukan pengkoordinasian tagihan -tagihan tugas terstruktur. Selanjutnya pada kegiatan ini pengabdi menggali permasalahan yang diharapi oleh perta dalam menyusun emateri Bhineka Tunggal Ika. Kendala yang dihadapi guru dalam penyusunan materi berpedoman pada buku pendamping dan suplemen bahan ajar (SBA) yang sudah terbiasa digunakan. Tindakan yang dilakukan yaitu dengan pembiasaan dan penyesuaian materi dengan isu kontemporer yang dekat dengan peserta didik. Sehingga peserta didik merasa lebih dekat terhadap contoh yang dipaparkan dalam materi Bhineka Tunggal Ika. Pada akhir sesi ini tim pengabdian bersama dengn peseerta mengelaborasikan kegiatan pelaihan dan pendampingan bahan ajar.

Hasil elaborasi dan tugas terstruktur tersebut kemudian disusun dalam sebuah materi bahan ajar dalam wujdu modul digital atau e-modul. Materi tersebut kemudaian disubmit melalui laman website. Dengan demikian materi akan lebih mudah diakses oleh peserta didik kapanpun, dan dimanapun keberadaannnya. 
Winarno Winanrno, dkk. Pelatihan dan Pendampingan Pengembangan Materi Pembelajaran PPKn Kajian Bhinneka Tunggal Ika Berbantuan Website

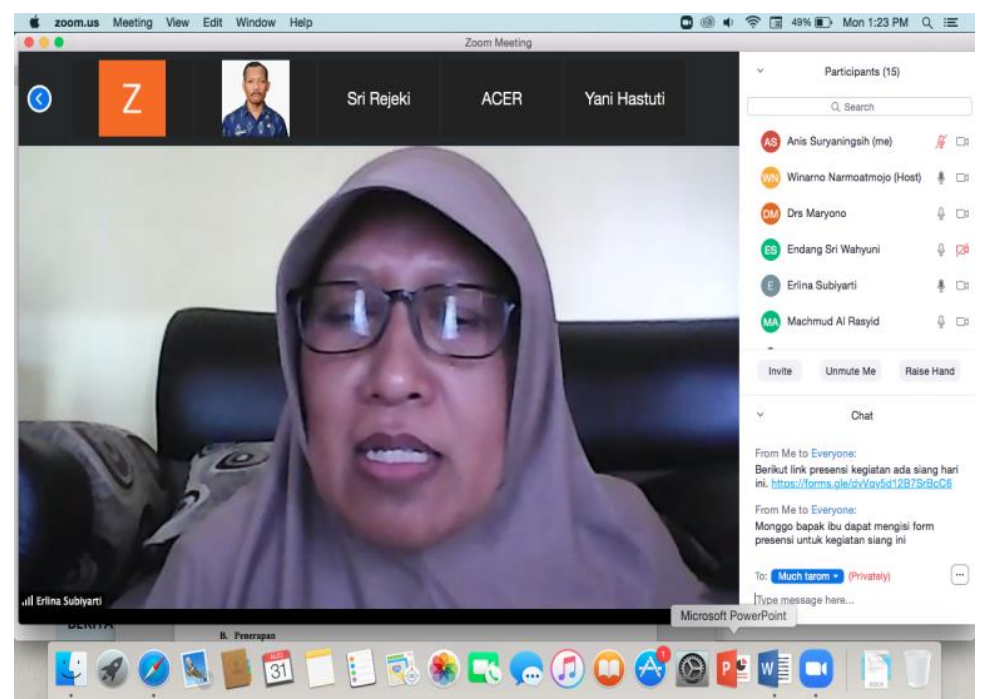

Gambar 2. Peserta memaparkan kendala dalam penyusunan bahan ajar.

\section{Kesimpulan}

Kegiatan pengabdian masyarakat pelatihan dan pendampingan Pengembangan Materi Pembelajaran PPKn Kajian Bhinneka Tunggal Ika Berbantuan Websitetelah berhasil diklaksanakan kepada guru-guru PPKn SMP Kabupaten Sukoharjo yang tergabung dalam MGMP PPKn SMP Kabupaten Sukoharjo. Dari pelaksanaan kegiatan dapat diketahui bahwa sebelum kegiatan, dalam penyampaian materi Bhinneka Tunggal Ika peserta berpedoman pada suplemen bahan ajar dan sebagian menggunakan buku pendamping. Kemudian dari pelaksanaan kegiatan ini peserta mampu menganaliss KI dan KD yang berkaitan dengan Bhinneka Tunggal Ika kemudian mengkaitkan dengan pokok pembahasan berupa keberagaman, isu kontemporer dan pentingnya persatuan dan diakhir kegiatan, tim pengabdi membimbing dan mendampingi peserta menyusun materii dalam bentuk emodul.

\section{Daftar Pustaka}

Al-Haj, A. (2005). National Ethos, Multicultural Education, And The New History Text Books in Israel. Curriculum. Inquiry, 35(1),47-71.

Anne, G . (2015). Security, Sovereignty, Patriotism-Sinhalese Nationalism and the State in SriLanka History Textbooks, Ethnopolitics.

Benito, A E. (2009). The manual as text: The construction of an identity. In A.van Gorp \& M. Depaepe (Eds.), Aufder Suchenachderwahren Artvon Textbu "chern (pp.37-49). Bad Heilbrunn: Klinkhardt

Khamid, N. (2016). Bahaya Radikalisme terhadap NKRI. Millati: Journal of Islamic Studies and Humanities. https://doi.org/10.18326/mlt.v1i1.123-152

Kemdikbud. (2016). Pendidikan Pancasila dan Kewarganegaraan SMP VII. Buku Guru. Jakarta: Kementrian Pendidikan dan Kebudayaan

Kompas. (2012). Kasus Lima Kasus Diskriminasi Terburuk Pascareformasi. Penulis: Sabrina Asril; Editor: Inggried Dwi Wedhaswary. https://nasional.kompas.com/read/201 2/12/23/15154962/Lima.Kasus.Diskriminasi.Terburuk.Pascareformasi

Mazid, S., \& Suharno, S. (2019). Implementasi nilai-nilai multikultural dalam pembelajaran PKn. Harmoni Sosial: Jurnal Pendidikan IPS, 6(1), 72-85.

MPR RI. ( 2012) . Empat Pilar Kehidupan Berbangsa dan Bernegara. Jakarta : Sekretariat MPR RI Muchith, M. S. (2016). Radikalisme dalam dunia pendidikan. Addin, 10(1), 163-180. 
Winarno Winanrno, dkk. Pelatihan dan Pendampingan Pengembangan Materi Pembelajaran PPKn Kajian Bhinneka Tunggal Ika Berbantuan Website

Opoku-Amankwa, Brew-Hammond, \& Kofigah. (2011). What is in a textbook? Investigating the language and literacy learning principles of the „Gateway to English" textbook series, Pedagogy, Culture \& Society, 19, 291-310.

Pusat Kurikulum dan Perbukuan. (2012). Penilaian Buku Teks Pelajaran. https://bsnpindonesia.org/category/evaluasi-buku/

Sapriya, S. (2012). Memperkokoh Posisi PKn Sebagai Disiplin Ilmu Terintegrasi. Pidato Pengukuhan Guru Besar bidang pembelajaran Pendidikan Kewarganegaraan FIPS. UPI Bandung.

Setyaningsih, U. (2017). Implementasi Nilai-Nilai Bhinneka Tunggal Ika pada Siswa Kelas Vii SMP Negeri 1 Surakarta pada Tahun Pelajaran 2016/2017. Uiversitas Muhammadiyah Surakarta.

Tim Pengembang MKDP Kurikulum dan Pembelajaran UPI. (2011). Kurikulum dan Pembelajaran. Bandung: UPI.

Utami, I. W. P., \& Widiadi, A. N. (2016). Wacana Bhineka Tunggal Ika Dalam Buku Teks Sejarah. Paramita: Historical Studies Journal. https://doi.org/10.15294/paramita.v26i1.5150

Wahid, A., Sunardi, D.A.K., \& Kurniawati, D.A. (2019). Membumikan konstitusi Indonesia Sebagai Upaya Menjaga Hak kebhinekaan. Yurispruden Fakultas Hukum Universitas Islam Malang. Universitas Negeri Malang.

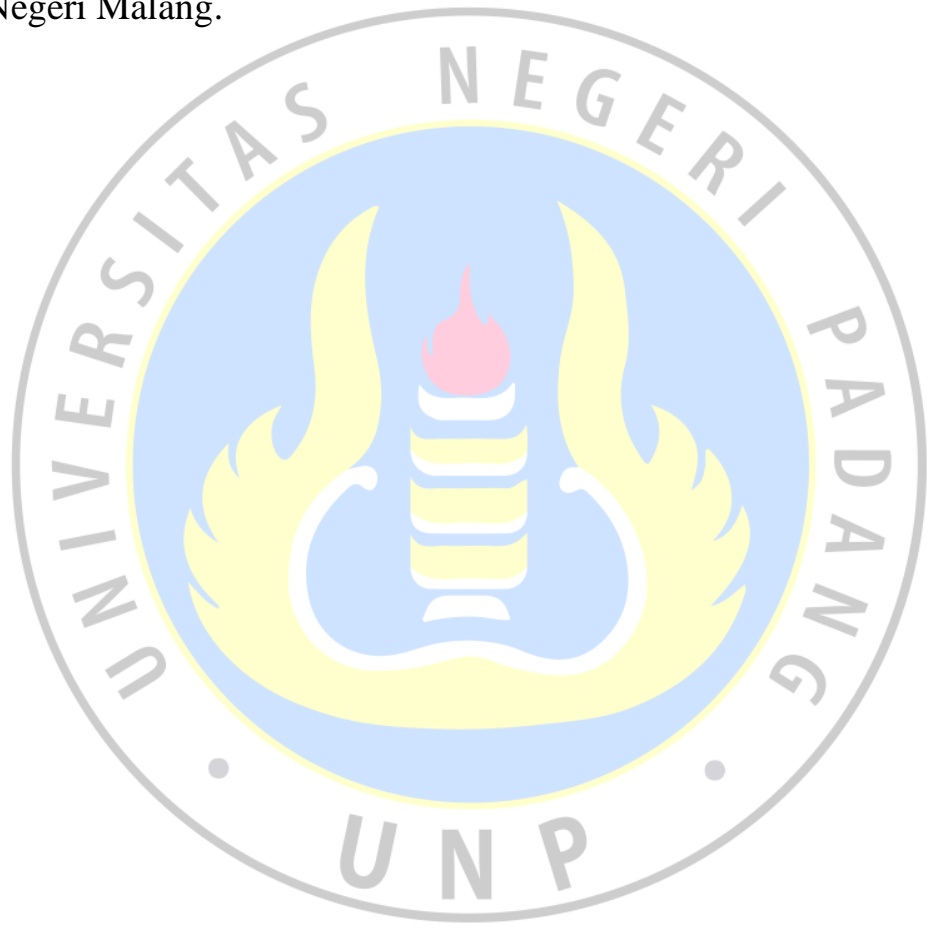

